\title{
EKSPLORASI KEKAYAAN KULINER MASYARAKAT SUKU DAYAK NGAJU DI DESA MANDOMAI KALIMANTAN TENGAH
}

\author{
Septo, Lala Aprilia Wulandari, Caroline Yunita Tiwo, Eri Yanti, Eli Karliani, \& Tryani \\ Universitas Palangka Raya \\ Septo0307@gmail.com
}

\begin{abstract}
Abstrak
Indonesia merupakan salah satu negara multikultural terbesar di dunia. Hal ini dapat dilihat dari kondisi sosio-kultural, agama maupun geografis yang begitu beragam dan luas. Sekarang ini, jumlah pulau yang ada di wilayah Negara Kesatuan republik Indonesia (NKRI) sekitar 13.000 pulau besar dan kecil. Populasi penduduknya berjumlah lebih dari 200 juta jiwa, terdiri dari 300 suku yang menggunakan hampir 200 bahasa yang berbeda. Kebudayaan yang biasa menjadi perhatian masyarakat adalah kebuadayaan makanan suatu daerah. Makanan seperti yang kita tahu merupakan suatu kebutuhan utama bagi manusia. Selain sebagai sumber energi dan tenaga, makanan juga memiliki makna dan nilai budaya tersendiri. Sistem Kuliner atau makanan khas dari setiap daerah memiliki keunikan tersendiri yang berbeda dari tiap daerah begitu pula di daerah Kalimantan Tengah. Hal inilah yang membuat makanan kami mangangkat Eksplorasi Kekayaan Kuliner Masyarakat Suku Dayak Kalimantan Tengah. Tujuan dari Penelitian ini untuk mengetahui apa saja ragam kekayaan kuliner Masyarakat Suku Dayak Ngaju di Desa Mandomai Kalimantan Tengah. Sebagai syarat menyelesaikan mata kuliah Seminar PPKn. Untuk mengetahui bagaimana upaya masyarakat dalam mempertahankan Kekayaan Kuliner Masyarakat Suku Dayak Ngaju Kalimantan Tengah. Kegiatan penelitian ini dilaksanakan selama 1 bulan, untuk di presentasikan dan diseminarkan. Kegiatan observasi kami laksanakan di daerah yang kami tentukan, untuk mewawancarai narasumber serta mengali informasi tentang rasa Kekayaan Kuliner Masyarakat Suku Dayak Ngaju di Desa Mandomai Kalimantan Tengah di daerah tersebut. Kalimantan Tengah merupakan Provinsi terbesar kedua setelah Papua, yang didominasi oleh penduduk Dayak, Jawa dan juga Banjar. Selain memiliki potensi alam yang indah, yang bisa dijadikan destinasi wisata, Kalimantan Tengah juga memiliki potensi wisata kuliner yang bisa dikenalkan hingga pelosok dunia. Berikut adalah beberapa daftar makanan khas Kalimantan Tengah: juhu umbut sawit, Kalumpe/kaluang, wadi, juhu taya, juhu umbut rotan, keripik kelakai, lemang, kue gagatas, dan masih banyak masakan atau ragam kuliner di daerah Kalimantan Tengah, yang masih dipertahankan dan masak dari dulu sampai sekarang ini.
\end{abstract}

Kata Kunci: Kuliner Dayak Ngaju, Masakan Tradisional Kalimantan Tengah, Kuliner Masyarakat Dayak Ngaju, Desa Mandomai

\begin{abstract}
Indonesia is one of the largest multicultural countries in the world. This can be seen from the sociocultural, religious and geographical conditions that are so diverse and broad. Currently, the number of islands in the territory of the Unitary State of the Republic of Indonesia (NKRI) is around 13,000 large and small islands. Its population is more than 200 million people, consisting of 300 tribes who speak almost 200 different languages. The culture that usually gets people's attention is the food culture of an area. Food as we know it is a basic need for humans. Apart from being a source of energy and energy, food also has its own cultural meaning and value. Culinary system or typical food from each region has its own uniqueness that is different from each region as well as in the Central Kalimantan area. This is what makes our food promote the Exploration of Culinary Wealth of the Central Kalimantan Dayak Tribe. The purpose of this study is to find out what are the various culinary riches of the Ngaju Dayak Tribe in Mandomai Village, Central Kalimantan. As a condition for completing the Civics Seminar course. To find out how the community's efforts in maintaining the Culinary Wealth of the Ngaju Dayak Tribe, Central Kalimantan. This research activity was carried out for 1 month, for presentation and seminars. Our observation activities were carried out in the areas that we determined, to interview sources and gather information about the taste of the Culinary Wealth of the Ngaju Dayak Tribe in Mandomai Village,
\end{abstract}


Central Kalimantan in the area. Central Kalimantan is the second largest province after Papua, which is dominated by the Dayak, Javanese and Banjar people. Besides having beautiful natural potential, which can be used as a tourist destination, Central Kalimantan also has the potential for culinary tourism that can be introduced to all corners of the world. The following is a list of typical Central Kalimantan foods: palm umbut juhu, Kalumpe/kaluang, wadi, juhu taya, rattan umbut juhu, kalakai chips, lemang, gagatas cake, and many other dishes or culinary varieties in the Central Kalimantan area, which are still preserved and preserved. cook from the past until now.

Keywords: Ngaju Dayak Culinary, Central Kalimantan Traditional Cuisine, Culinary of the Ngaju Dayak Community, Mandomai Village

\section{PENDAHULUAN}

Indonesia merupakan salah satu negara multikultural terbesar di dunia. Hal ini dapat dilihat dari kondisi sosio-kultural, agama maupun geografis yang begitu beragam dan luas. Sekarang ini, jumlah pulau yang ada di wilayah Negara Kesatuan republik Indonesia (NKRI) sekitar 13.000 pulau besar dan kecil. Populasi penduduknya berjumlah lebih dari 200 juta jiwa, terdiri dari 300 suku yang menggunakan hampir 200 bahasa yang berbeda (Moleong, 2010).

Kebudayaan yang biasa menjadi perhatian masyarakat adalah kebuadayaan makanan suatu daerah. Makanan seperti yang kita tahu merupakan suatu kebutuhan utama bagi manusia. Selain sebagai sumber energi dan tenaga, makanan juga memiliki makna dan nilai budaya tersendiri. Sistem Kuliner atau makanan khas dari setiap daerah memiliki keunikan tersendiri yang berbeda dari tiap daerah begitu pula di daerah Kalimantan Tengah. Hal inilah yang membuat makanan kami mangangkat Eksplorasi Kekayaan Kuliner Masyarakat Suku Dayak Kalimantan Tengah. (Alexandro, Uda, \& Pane, 2020) (Inah, 2013).

Suku dayak pada umumnya mempunyai warisan kearifan lokal memanfaatkan sumber daya alam yang ada disekitar lingkungan mereka dalam hal ini pemanfaatan tumbuhan liar sebagai makanan mereka sehari-hari sumber tumbuhan liar tersebut ada yang tinggal tengah hutan atau disekitar perkarangan rumah (Alexandro, Uda, \& Pane, 2020).
Kuliner adalah segala sesuatu yang berhubungan dengan makanan dan merambah ranah wisata. Istilah wisata kuliner menjadi tren, karena selain makan, orang-orang juga dapat berwisata dan dapat memenuhi hasrat aktualisasi diri di media sosial dengan mengunggah foto-foto wisata kuliner mereka pada media sosial pribadi. Dengan demikian, tidak dapat dimungkiri pada akhirnya kuliner menjadi salah satu andalan pariwisata daerah di Indonesia. Salah satu daerah yang memiliki kekayaan kuliner dan kekayaan alam yang unik adalah Kalimantan. Penduduk asli pulau ini ialah masyarakat suku Dayak. Mereka memiliki beragam kuliner yang lezat dan sehat dengan cara pengolahan yang unik pula. Namun, kekayaan kuliner masyarakat Dayak kurang populer jika dibandingkan dengan kuliner masyarakat di daerah Sumatra Barat, misalnya, yang sangat terkenal dengan rendangnya yang mendunia. Oleh karena itu, peneliti tertarik untuk mengenalkan kuliner masyarakat Dayak, khususnya dalam penelitian ini, melalui nama-nama kuliner pada masyarakat dayak. (Alexandro, Uda, \& Pane, 2020).

Ekonomi kreatif telah lama dicanangkan sebagai gerakan ekonomi yang bersumber dari masyarakat lokal sebagai pelaku ekonomi, sehingga masyarakat dituntut untuk memiliki kreativitas dan ketekunan yang optimal untuk dapat mencapai tujuan pertumbuhan nasional (Nurgiansah, 2021b). Selama ini produk ekonomi kreatif dikembangkan oleh UMKM yang diupayakan oleh 
pemerintah sebagai pewarisan jati diri bangsa. Sumbangan sektor ekonomi kreatif bagi pembangunan perekonomian Indonesia antara lain berupa peningkatan PDB, penyerapan tenaga kerja, peningkatan ekspor, pembukaan lapangan usaha baru dan terbarukan serta menciptakan dampak bagi sektor lainnya (Be Kraf, 2016) (Nurgiansah, 2020).

Secara universal, ekonomi kreatif juga memberikan dampak sosial seperti peningkatan kualitas hidup, pemerataan kesejahteraan dan peningkatan toleransi sosial. Dampak yang lain yang ditimbulkan oleh ekonomi kreatif adalah menciptakan pembaharuan sumber daya yang berbasis pengetahuan, komunitas dan green community (Be Kraf, 2016).

Melihat perkembangan aktivitas kreatif yang semakin marak digulirkan di berbagai wilayah disertai dengan semakin tingginya antusias berbagai kota dan daerah untuk menjadi kota kreatif turut mengindikasikan bahwa ekonomi kreatif telah mengambil peran dalam aktivitas perekonomian nasional. Setiap daerah/wilayah pada umumnya memiliki potensi produk yang bisa di angkat dan dikembangkan termasuk di dunia pendidikan (Sukardi, 2017) (Nurgiansah, 2021a).

Keunikan atau kekhasan produk lokal itulah yang mesti menjadi intinya lalu ditambah unsur kreatifitas dengan sentuhan teknologi. Selain itu perlu ada pelatihan khusus yang bisa meningkatkan kemampuan masyarakat dalam mengembangkan idenya (Moenada \& Riofita, 2018) (Nurgiansah, 2021c).

Berdasarkan pemetaan industri kreatif yang telah dilakukan oleh Departemen Perdagangan Republik Indonesia terdapat 14 subsektor industri kreatif di Indonesia, yakni periklanan, arsitektur, pasar barang seni, kerajinan, desain, fashion, video, film dan photografi, permainan interaktif, musik, seni pertunjukan, penerbitan dan percetakan, layanan komputer dan peranti lunak, televisi dan radio serta riset dan pengembangan. Pertumbuhan ekspor industri kreatif tahun 2006-2009 tercatat sebesar 2,9\% kemudian ditahun 2015 telah meningkat menjadi 16 subsektor yaitu kuliner, fashion, kriya atau kerajinan tangan, televisi dan radio, penerbitan, arsitektur, aplikasi dan game developer (Alexandro, Uda, \& Pane, 2020) (Nurgiansah, 2021d).

Kalimantan Tengah sebenarnya adalah daerah yang memiliki potensi untuk memaksimalkan ekonomi kreatif dengan kearifan lokal yang dimilikinya, namun dalam praktiknya Kalimantan Tengah belum optimal menggaungkan ciri khas daerahnya di kancah nasional khususnya dalam bidang industri kuliner. Bidang kuliner Kalimantan Tengah merupakan salah satu bidang yang memiliki keanekaragaman yang bisa diangkat dan diperkenalkan lebih luas ke luar Kalimantan Tengah. Produk yang dihasilkan dalam ekonomi kreatif di Kalimantan Tengah umumnya bersumber dari nilai-nilai kearifan lokal yang dianut masyarakat khususnya masyarakat Suku Dayak yang mendiami Provinsi Kalimantan Tengah.

Kota Palangka Raya yang merupakan ibukota Provinsi Kalimantan Tengah memiliki berbagai kuliner khas daerah yang sangat unik dan menggugah selera, misalnya seperti Juhu Rotan, Juhu Asem, Oseng Kalakai (Pakis), Kandas, Ikan Bakar, Wadi, Tumbuk Daun Singkong, Terong Bapapui, dll. Sedangkan Oleh-oleh/Cemilan yang terkenal dari Kota Palangka Raya berupa Lemang, Amplang Ikan Pipih/Haruan, Keripik Kelakai, Lempok Dahuyan, Saluang Goreng, Abon Ikan Pipih dan lain-lain. Saat ini, kuliner tersebut hanya dapat ditemui di kalangan tertentu dan dinikmati dalam waktu tertentu saja. 
Dengan demikian sesuai dengan analisis gap di atas maka penelitian ini bertujuan untuk menganalisis lebih mendalam pengembangan ekonomi kreatif sektor kuliner khas suku dayak di Kalimantan Tengah. Tujuan penelitian ini juga untuk merealisasikan potensi ekonomi daerah menjadi pertumbuhan ekonomi yang tinggi, perekonomian masyarakat melalui upaya-upaya yang akan ditemukan melalui analisis penelitian ini (Alexandro, Uda, \& Pane, 2020).

Makanan merupakan salah satu aspek kebudayaan dalam setiap masyarakat. Dengan semakin majunya masyarakat maka makanan tradisional semakin hari semakin ditinggalkan oleh masyarakat pendukungnya. Dalam upaya meningkatkan mutu pangan dan sekaligus untuk tetap memelihara pelestarian makanan tradisional, masyarakat perlu ditumbuhkan sikap bangga terhadap basil budayanya.

Disebabkan kebutuhan akan beras terns menerus meningkat. Di sisi yang lain pengadaan beras itu sendiri dari hari ke hari semakin kalah dibanding pertumbuhan penduduk di Indonesia. Selaras sengan tujuan pemerintah tersebut, tulisan ini akan mencoba mendiskripskan makanan dan tradisi makan pada masyarakat Dayak terutamam mengenai: Bagaiman tradisi makan pada masyarakat Dayak Bagaiman masyarakat tersebut memperoleh bahan makanan Variasi makanan yang bagaiman dilakukan masyarakat setempat Simbol-simbol apa yang ada pada makanan Dayak, terutama yang berkaitan dengan upacara.

Dayak merupakan salah satu suku Nusantara yang mendiami daratan Kalimantan dan terkenal akan kebudayaannya yang sangat kaya. Kekayaan budaya yang dimiliki masyarakat Dayak tak hanya bisa dilihat dari kekayaan tradisi, kesenian hingga adat-istiadat, namun juga kekayaan kuliner khas Dayak yang resepnya masih terjaga hingga kini. Kalimantan Tengah sebenarnya adalah daerah yang memiliki potensi untuk memaksimalkan ekonomi kreatif dengan kearifan lokal yang dimilikinya, namun dalam praktiknya Kalimantan Tengah belum optimal menggaungkan ciri khas daerahnya di kancah nasional khususnya dalam bidang industri kuliner. Bidang kuliner Kalimantan Tengah merupakan salah satu bidang yang memiliki keanekaragaman yang bisa diangkat dan diperkenalkan lebih luas ke luar Kalimantan Tengah.

Produk yang dihasilkan dalam ekonomi kreatif di Kalimantan Tengah umumnya bersumber dari nilai-nilai kearifan lokal yang dianut masyarakat khususnya masyarakat Suku Dayak yang mendiami Provinsi Kalimantan Tengah. Kota Palangka Raya yang merupakan ibukota Provinsi Kalimantan Tengah memiliki berbagai kuliner khas daerah yang sangat unik dan menggugah selera, misalnya seperti Juhu Rotan, Juhu Asem, Oseng Kalakai (Pakis), Kandas, Ikan Bakar, Wadi, Tumbuk Daun Singkong, Terong Bapapui, dll. Sedangkan Oleh-oleh/Cemilan yang terkenal dari Kota Palangka Raya berupa Lemang, Amplang Ikan Pipih/Haruan, Keripik Kelakai, Lempok Dahuyan, Saluang Goreng, Abon Ikan Pipih dan lain-lain. Saat ini, kuliner tersebut hanya dapat ditemui di kalangan tertentu dan dinikmati dalam waktu tertentu saja.

Dengan demikian sesuai dengan analisis gap di atas maka penelitian ini bertujuan untuk menganalisis lebih mendalam pengembangan ekonomi kreatif sektor kuliner khas suku dayak di Kalimantan Tengah. Tujuan penelitian ini juga untuk merealisasikan potensi ekonomi daerah menjadi pertumbuhan ekonomi yang tinggi, yang menghasilkan lapangan pekerjaan yang layak dan meningkatkan kemandirian perekonomian masyarakat 
melalui upaya-upaya yang akan ditemukan melalui analisis penelitian ini.

Makanan adalah salah satu kebutuhan pokok manusia. Makanan yang dikonsumsi manusia dianjurkan mengandung gizi yang sesuai dengan kebutuhan tubuh. Indonesia yang terkenal dengan keanekaragaman budayanya, juga memiliki keanekaragaman dalam makanannya. Setiap suku di Indonesia mempunyai masakan khas yang berbeda dengan cita rasa yang berbeda pula. Jika diolah secara profesional menjadi makanan khas dan sajian kuliner yang lezat, kuliner Indonesia dapat meningkatkan pendapatan ekonomi masyarakat dan menjadi identitas bangsa.

Kuliner menjadi sangat penting sebagai budaya bangsa. Indonesia memiliki banyak keanekaragaman makanan yang berbeda antar daerah, harus dijaga agar tidak diklaim oleh negara lain. Seperti halnya tarian, kuliner adalah bagian dari identitas Budaya Indonesia (Wongso, 2015).

Saat ini banyak orang yang mulai meninggalkan kuliner traditional dan mulai terpengaruh dengan budaya luar seperti jenis-jenis makanan yang kita konsumsi seperti KFC, steak, burger, dan lain-lain. Masyarakat menganggap makanan tersebut hieginis, modern, dan praktis. Tanpa kita sadari makanan-makanan tersebut juga telah menjadi menu keseharian dalam kehidupan kita. Hal ini mengakibatkan makin langkanya berbagai jenis makanan tradisional. jika hal ini terus terjadi maka tak dapat dihindarkan bahwa anak cucu kita kelak tidak tahu akan jenisjenis makanan tradisional yang berasal dari daerah asal mereka (Alexandro, Uda, \& Pane, 2020).

\section{METODE PENELITIAN}

Lokasi penelitian dilakukan di Desa Mandomai, Kecamatan Kapuas Barat, Kabupaten Kapuas, Provinsi Kalimantan
Tengah. Kegiatan penelitian ini dilaksanakan selama 1 bulan, untuk di presentasikan dan diseminarkan. Kegiatan observasi kami laksanakan di daerah yang kami tentukan, untuk mewawancarai narasumber serta mengali informasi tentang rasa Kekayaan Kuliner Masyarakat Suku Dayak Ngaju di Desa Mandomai Kalimantan Tengah di daerah tersebut. Pendekatan yang digunakan dalam penelitian ini adalah pendekatan kualitatif, pendekatan kualitatif adalah suatu prosedur penelitian yang menghasilkan data deskriptif berupa kata-kata atau lisan orang-orang dan perilaku yang dapat diamati. Pendekatan kualitatif memiliki karakteristik alami (natural Serfing) sebagai sumber data langsung, deskriptif, proses lebih penting dari hasil. Analisis induktif dan makna-makna merupakan hal yang esensial (Meleong, 2013).

Objek dalam penelitian kualitatif adalah objek yang alamiah, atau natural setting, sehingga penelitian ini sering disebut penelitian naturalistic. Obyek yang alami adalah objek yang apa adanya, tidak dimanipulasi oleh peneliti sehingga kondisi pada saat peneliti memasuki objek, setelah berada di objek dan keluar dari objek relatif tidak berubah. Dalam penelitian kualitatif peneliti menjadi instrumen. Oleh karena itu dalam penelitian kualitatif instrumennya adalah orang atau Human instrument. Untuk menjadi instrumen peneliti harus memiliki bekal teori dan wawasan yang luas, sehingga mampu bertanya, menganalisis, memotret dan mengkontruksi objek yang diteliti menjadi jelas dan bermakana. Kriteria data dalam penelitian kualitatif adalah data yang pasti. Data yang pasti adalah data yang sebenarnya terjadi sebagaimana adanya, bukan data yang sekedar terlihat, terucap, tetapi data yang mengandung makna dibalik yang terlihat dan terucap tersebut (Sugiyono, 2008). 
Motode penelitian data yang digunakan dalam proposal kami adalah sebagai berikut

\section{Observasi}

Pengamatan atau observasi adalah aktivitas terhadap suatu proses atau objek dengan maksud merasakan dan kemudian memahami pengetahuan dari sebuah fenomena berdasarkan pengetahuan dan gagasan yang sudah diketahui sebelumnya, untuk mendapatkan informasi-informasi yang dibutuhkan untuk melanjutkan suatu penelitian .

\section{Wawancara}

Wawancara adalah kegiatan tanyajawab secara lisan untuk memperoleh informasi. Bentuk informasi yang diperoleh dinyatakan dalam tulisan, atau direkam secara audio, visual, atau audio visual. Wawancara merupakan kegiatan utama dalam kajian pengamatan. Pelaksanaan wawancara dapat bersifat langsung maupun tidak langsung. Wawancara langsung dilakukan dengan menemui secara langsung orang yang memiliki informasi yang dibutuhkan, sedangkan wawancara tidak langsung dilakukan dengan menemui orang-orang lain yang dipandang dapat memberikan keterangan mengenai keadaan orang yang diperlukan datanya. Pertukaran informasi dan ide melalui tanya-jawab dimaksudkan untuk membentuk makna dalam suatu topik tertentu. Wawancara digunakan dalam penelitian untuk mengatasi kelemahan metode observasi dalam pengumpulan data. Informasi dari narasumber dapat dikaji lebih mendalam dengan memberikan interpretasi terhadap situasi dan fenomena yang terjadi.

\section{Dokumesntasi}

Teknik pengumpulan data dengan menggunakan dokumentasi merupakan suatu teknik pengumpulan data dengan menghimpun dan menganalisis dokumen- dokumen, baik tertulis, gambar, maupun elektronik. Studi dokumen merupakan pelengkap dari penggunaan metode observasi dan wawancara dalam penelitian kualitatif. Hasil penelitian dari observasi atau wawancara, akan lebih kredibel dan dapat dipercaya kalau didukung oleh dokumen-dokumen dari narasumber (Sukmadinata, 2013).

\section{HASIL PENELITIAN DAN PEMBAHASAN Hasil Penelitian}

Berdasar surat izin penelitian penulis telah mengadakan penelitian dengan menggunakan teknik observasi, wawancara dan dokumentasi. Terhadap hasil wawancara akan penulis sajikan menjadi satu dengan penyajian data hasil observsi, data hasil wawancara dan dokumentasi, dapat penulis sajikan sebagai berikut :

1. Ragam kekayaan kuliner masyarakat Suku Dayak Ngaju di Desa Manomai Kalimantan

Tengah. Kalimantan Tengah merupakan Provinsi terbesar kedua setelah Papua, yang didominasi oleh penduduk Dayak, Jawa dan juga Banjar. Selain memiliki potensi alam yang indah, yang bisa dijadikan destinasi wisata, Kalimantan Tengah juga memiliki potensi wisata kuliner yang bisa dikenalkan hingga pelosok dunia. Berikut adalah beberapa daftar makanan khas Kalimantan Tengah:

a) Juhu Umbut Rotan

Umbut Rotan atau dikenal uwut nang'e adalah kuliner suku Dayak yang berbahan dasar rotan muda. Rotan tersebut dibersihkan kemudian dibuang kulitnya dan dipotong dalam ukuran kecil. Umbut Rotan dimasak bersama dengan ikan baung, bumbu, dan terong asam. Rasa yang gurih, asam, dan sedikit pahit, yang dipadukan dengan manisnya daging ikan menjadi ciri khas dari kuliner ini.

b) Juhu Umbut Sawit 
Juhu Umbut Sawit merupakan makanan terpopuler yang paling banyak dicari oleh para pecinta kuliner yang datang ke Kalimantan Tengah. Makanan ini menjadi kuliner terfavorit dan wajib dihidangkan dalam acara-acara besar seperti syukuran karena rasanya yang gurih, nikmat, dan juga sangat lezat.

\section{c) Kalumpe / Karuang}

Kalumpe / Karuang yaitu sayuran yang terbuat dari daun singkong yang telah ditumbuk hingga halus. Istilah Kalumpe digunakan dalam bahasa Dayak Maanyan, sedangkan Karuang digunakan dalam bahasa Dayak Ngaju. Kalumpe diolah dengan cara menumbuk daun singkong hingga halus yang dicampur dengan terong kecil atau terong pipit, ditambah dengan bumbu bawang merah, bawang putih, serai, dan lengkuas yang sudah dihaluskan. Umumnya kuliner ini disajikan bersama dengan sambal terasi.

\section{d) Wadi}

Wadi merupakan makanan yang berbahan dasar ikan atau terkadang menggunakan daging babi. Cara membuatnya yaitu dengan terlebih dahulu membersihkan ikan atau daging, kemudian direndam selama 5-10 jam dalam air garam. Lalu daging atau ikan tersebut diangkat dan dibiarkan mengering. Setelah kering, ikan atau daging tersebut dicampur dengan Sa'mu hingga rata dan disimpan dalam wadah yang kedap udara dan tertutup rapat. Simpan selama 3-5 hari untuk ikan dan seminggu lebih untuk daging. Sebelum disantap, wadi harus digoreng atau dimasak terlebih dahulu.

\section{e) Juhu taya}

Juhu Taya dengan ikan bapuyu, yaitu masakan berkuah Pengolahan juhu taya sama dengan juhu-juhu masyarakat Dayak pada umumnya, bumbu-bumbunya pun sama. Yang membedakan tentu saja rasa khas dari daun taya itu sendiri. Dalam pengolahan sayur-sayuran, suku Dayak sangat menggemari sayuran berkuah dengan bumbu-bumbu yang sama, hanya bahan yang berbeda-beda.

\section{f) Juhu umbut rotan}

Pulau Kalimatan yang sebagian besar alamnya didominasi oleh hutan tropis ternyata mempunyai pengaruh terhadap khazanah perkulinerannya. Jika selama ini kamu pernah mendengar rebung, di Kalimantan, tepatnya di kota Palangkaraya, Kalimantan Tengah, juga terdapat makanan sejenis rebung yang bernama juhu umbut rotan. Bahan yang digunakan sama seperti rebung yakni rotan yang masih muda. Juhu umbut rotan adalah makanan khas Kalimantan Tengah yang menggunakan ujung rotan yang masih muda. Proses pembuatan makanan tradisional ini membutuhkan tenaga ekstra pada saat menghilangkan duri-duri yang mengitari batang rotan. Rotan kemudian dipotong kecil-kecil dan diberi bumbu rempah tertentu. Umbu rotan bisa dimasak bersama santan ataupun tidak. Penyajian umbu rotan dilakukan bersama kuliner lain seperti ikan patin atau nila bakar. Nenek moyang masyarakat keturunan Dayak yang menetap di Kalteng pada zaman dulu hidup harmonis dengan alam. Hutan telah menjadi sumber penghidupan bagi mereka sehingga tak jarang flora yang terdapat di dalam hutan dimanfaatkan untuk kebutuhan perut oleh mereka. Tanaman kelakai adalah salah satu tanaman yang telah alam dimanfaatkan oleh masyarakat suku Dayak di Kalimantan Tengah.

\section{g) Tanaman kelakai}

Dipercaya mampu mengobati diare, menambah darah, dan menjaga kulit awet muda. Kelakai biasanya diolah menjadi kuliner sejenis camilan, semisal keripik. Keripik kelakai adalah makanan khas Kalimantan Tengah yang dibuat oleh suku 
Dayak dengan memanfaatkan bagian daunnya yang masih muda. Daun kelakai kemudian dibaluri adonan tepung bumbu dan digoreng pada minyak panas. Keripik kelakai yang sudah jadi mempunyai rasa yang gurih dan teksturnya sangat renyah di mulut.

\section{h) Lemang}

Adalah makanan yang menurut sejarah pertama kali dibuat oleh bangsa Melayu. Penyebaran masyarakat suku Melayu yang begitu masif hingga ke Indonesia membuat makanan satu ini terdapat di bagian utara Indonesia. Seperti di Kalimantan yang cukup banyak dihuni oleh penduduk Melayu sehingga membuat sebagian orang mengira lemang adalah makanan khas Kalimantan Tengah. Selain suku Melayu, suku Dayak juga menjadikan lemang sebagai panganan yang disajikan pada pesta-pesta adat mereka. Lemang merupakan makanan sejenis lontong atau ketupat yang dibuat dari bahan baku beras ketan. Pengolahan dari beras ketan hingga menjadi lemang melewati proses pematangan yang unik, yakni dimasak dalam seruas bambu. Sebelum dimasukkan ke dalam bambu, terlebih dahulu beras ketan digulung dengan daun pisang atau daun bambu. Selain di provinsi Kalteng, lemang juga banyak ditemui di provinsi Kalimantan Selatan. Lemang biasanya disajikan bersama lauk asin ataupun tidak, tergantung selera.

\section{i) Kue gagatas atau kue getas}

Adalah kue tradisional yang terbuat dari beras ketan. Dahulu penduduk Kalteng banyak yang memakan kue gagatas saat terjadi paceklik. Selain di Kalimantan, kue getas juga bisa ditemui di kota Surabaya dan sekitarnya. Kue satu ini banyak dijual di pasar tradisional sebagai jajanan atau camilan. Harga pasaran kue gagatas juga sangat ramah di kantong sehingga tak heran jika kue ini memiliki banyak peminat. Kue gagatas mempunyai bentuk lonjong menyerupai telur. Meski demikian, ada juga pembuat yang membentuk kuenya lonjong agak pipih dan di bagian luarnya terdapat lapisan gula sehingga menimbulkan daya pikat tersendiri dari kue ini. Kue gagatas banyak disantap oleh [bukan hanya] penduduk Kalteng sebagai camilan menanti senja. Hampir semua makanan khas Kalimantan Tengah lahir lewat tangan penduduknya yang berasal dari tiga suku berbeda, yakni Banjar, Dayak, dan Jawa [terutama dari suku Dayak]. Apabila kamu berencana untuk menjadikan Kalteng sebagai obyek tujuan wisata ketika momen libur tiba, jangan lupa untuk menyicip beberapa kuliner asal Kalimantan Tengah yang telah tercantum pada daftar tersebut di atas.

Dan masih banyak masakan atau ragam kuliner di daerah Kalimantan Tengah, yang masih dipertahankan dan masak dari dulu sampai sekarang ini.

1) Menurut Narasumber Pertama :

Makanan yang biasanya digunakan untuk acara Adat/nikahan atau makanan yang harus ada di dalam acara tersebut. Wadai Apam (Kue Apem), dan Pulut (ketang). Makanan yang masih kental di daerah Mandomai. Rebusan daun Singkong, Rebusan Kacang Panjang, Rebusan Terong, Kuah Rotan yang masih Muda, Kue Lemang, Kue Cucur, dan Kue Kukuleh.

\section{2) Menurut Narasumber Kedua :}

Makanan daerah kita Dayak ini cenderungnya ke mana $\mathrm{Bu}$, apakah cenderung ke pedas, manis atau asin. Nah, kalua kita Dayak itu makanan nya semua bisa kita masak, tidak cenderung ke manamana, tergantung ke selera kita memasak.

Makanan di daerah mandomai ini Ibu yang sering dimasak. Kalau untuk masakan itu ibu tidak menentu untuk memasak masakannya karena oleh faktor usia juga, jadi cuman bisa masak juhu asem, juhu kanas saja. 


\section{3) Menurut Narasumber Ketiga :}

Di Acara-acara adat atau pernikahan yang harus ada di masak di Desa Mandomai ini apa saja. Biasanya itu di daerah kami, Juhu singkah sawit, Opor ayam. Makanan daerah Desa Mandomai ini yang masih di pertahankan dari dahulu sampai sekarang. Kue Kaluleh, Kue Tanteluh Karulang, Cucur, Gegatas, Juhu Batang Pisang. Makanan di daerah Desa Mandomai ini lebih cenderung ke Pedas, Manis, atau Asin lebih enderung ke Asin dan Pedas.

2. Upaya masyarakat suku Dayak ngaju di desa Mandomai kalimantan tengah mempertahankan kekayaan kuliner. Upaya masyarakat suku Dayak Ngaju Kalimantan Tengah di desa Mandomai di dalam penelitian kami, yaitu :

Yang terutama karena makanan kita itu sudah pasti cocok di lidah kita, dan memang sudah khas punya kita makanannya, dan oleh karena makanan daerah kita sudah ada sejak orang tua kita lahir, oleh karena itu harus ada kita makanan merasakan makanan daerah kita. Karena di tradisi kita Dayak ini segala jahe, serai, kunyit, itu diharuskan kita untuk memasukan ke makanan kita, dan tidak ada sifat yang lain, cuman kita sebagai masyarakat Dayak tidak bisa meninggalkan tradisi masakan daerah kita.

\section{Dinamika perkembangan ragam kekayaan kuliner masyarakat dayak ngaju kalimantan tengah di masa era modern.}

Ekonomi kreatif di era digital saat ini semakin berkembang, selain menawarkan peluang, namun juga memunculkan persaingan, misalnya dalam dunia kuliner yang memberikan tantangan tersendiri bagi Kota Palangka Raya yaitu bagaimana mengangkat dan mengembangkan kuliner khas daerah di tengah maraknya kuliner modern. Tujuan penelitian ini adalah untuk menganalisis dan mengetahui pengembangan ekonomi kreatif di Kota Palangka khususnya pada sektor kuliner oleh-oleh khas Suku Dayak Kalimantan Tengah.

\section{Pembahasan}

Jenis penelitian ini adalah penelitian kualitatif yang dianalisis menggunakan metode deskriptif. Teknik pengumpulan data yang dilakukan dalam penelitian yaitu dihimpun dari observasi, wawancara mendalam, studi literatur dan dokumentasi, kemudian dilakukan teknik analisis data yang dikembangkan oleh Miles, Huberman dan Saldana menggunakan empat alur kegiatan dalam analisis data yaitu, pengumpulan data, kondensasi data, penyajian data, serta penarikan kesimpulan.

Hasil penelitian menemukan bahwa pengembangan ekonomi kreatif oleh-oleh kuliner khas Kalimantan Tengah di MEFs Food \& Snacks berjalan dengan baik dan berpotensi unggul di tengah persaingan yang ketat terutama dengan kuliner modern. Selain itu, hal ini berimplikasi pada perilaku ekonomi produsen yaitu semakin termotivasi untuk mengeksplor makanan khas Kalimantan Tengah yang dapat di angkat dan diperkenalkan ke luar daerah. Kalimantan Tengah sebenarnya adalah daerah yang memiliki potensi untuk memaksimalkan ekonomi keatif dengan kearifan lokal yang dimilikinya, namun dalam praktiknya Kalimantan Tengah belum optimal menggaungkan ciri khas daerahnya di kancah nasional khususnya dalam bidang industri kuliner.

Bidang kuliner Kalimantan Tengah merupakan salah satu bidang yang memiliki keanekaragaman yang bisa diangkat dan diperkenalkan lebih luas ke luar Kalimantan Tengah. Produk yang dihasilkan dalam ekonomi kreatif di Kalimantan Tengah umumnya bersumber dari nilai-nilai kearifan lokal yang dianut 
masyarakat khususnya masyarakat Suku Dayak yang mendiami Provinsi Kalimantan Tengah.

Kota Palangka Raya yang merupakan ibukota Provinsi Kalimantan Tengah memiliki berbagai kuliner khas daerah yang sangat unik dan menggugah selera, misalnya seperti Juhu Rotan, Juhu Asem, Oseng Kalakai (Pakis), Kandas, Ikan Bakar, Wadi, Daun Singkong, Terong Bapapui, dll. Sedangkan Oleh-oleh/Cemilan yang terkenal dari Kota Palangka Raya berupa Lemang, Amplang Ikan Pipih/Haruan, Keripik Kelakai, Lempok Dahuyan, Saluang Goreng, Abon Ikan Pipih dan lain-lain. Saat ini, kuliner tersebut hanya dapat ditemui di kalangan tertentu dan dinikmati dalam waktu tertentu saja.

Dengan demikian sesuai dengan analisis gap di atas maka penelitian ini bertujuan untuk menganalisis lebih mendalam pengembangan ekonomi kreatif sektor kuliner khas suku dayak di Kalimantan Tengah. Tujuan penelitian ini juga untuk merealisasikan potensi ekonomi daerah menjadi pertumbuhan ekonomi yang tinggi, yang menghasilkan lapangan pekerjaan yang layak dan meningkatkan kemandirian perekonomian masyarakat melalui upaya-upaya yang akan ditemukan melalui analisis penelitian ini (Alexandro, Uda, \& Pane, 2020).

Suku Mempunyai Dayak Warisan pada kearifan umumnya local memanfaatkan sumber daya alam yang ada di sekitar lingkungan mereka dalam hal ini pemanfaatan tumbuhan liar sebagai makanan mereka sehari-hari. Sumber tumbuhan liar tersebut ada yang tinggal di tengah hutan atau di sekitar daerah rawa, di pinggir sungai, di kebun atau di sekitar pekarangan rumah. Sudah ada beberapa dokumentasi dan referensi mengenai keanekaragaman sayuran lokal masyarakat yang ada di Kalimantan Tengah (Irawan et al, 2006; Chotimah dkk, 2011; Chotimah etal., 2013), tetapi masih agak jarang didalami lebih spesifik mengenai sayuran lokal yang berada di daerah rawa atau daerah pinggir sungai.

Mengonsumsi sayuran lokal ternyata tanda disadari oleh masyarakat suku Dayak ternyata telah menerapkan pola hidup sehat karena menggunakan sayur organik dan telah menjaga kelestarian alam dari pencemaran lingkungan karena terpapar pestisida kimia atau pupuk kima yang berlebihan. Pada saat ini terjadi peningkatan minat masyarakat untuk mengonsumsi sayuran organik Rahmawati (2018).

\section{KESIMPULAN}

Kalimantan Tengah merupakan Provinsi terbesar kedua setelah Papua, yang didominasi oleh penduduk Dayak, Jawa dan juga Banjar. Selain memiliki potensi alam yang indah, yang bisa dijadikan destinasi wisata, Kalimantan Tengah juga memiliki potensi wisata kuliner yang bisa dikenalkan hingga pelosok dunia. Berikut adalah beberapa daftar makanan khas Kalimantan Tengah: juhu umbut sawit, Kalumpe/kaluang, wadi, juhu taya, juhu umbut rotan, keripik kelakai, lemang, kue gagatas, dan masih banyak masakan atau ragam kuliner di daerah Kalimantan Tengah, yang masih dipertahankan dan masak dari dulu sampai sekarang ini.

Upaya masyarakat suku Dayak Kalimantan Tengah di desa Mandomai di dalam penelitian kami, yaitu : Yang terutama karena makanan kita itu sudah pasti cocok di lidah kita, dan memang sudah khas punya kita makanannya, dan oleh karena makanan daerah kita sudah ada sejak orang tua kita lahir, oleh karena itu harus ada kita makanan merasakan makanan daerah kita. Karena di tradisi kita Dayak ini segala jahe, serai, kunyit, itu diharuskan kita untuk memasukan ke makanan kita, dan tidak ada sifat yang lain, cuman kita sebagai masyarakat Dayak 
tidak bisa meninggalkan tradisi masakan daerah kita.

Ekonomi kreatif di era digital saat ini semakin berkembang, selain menawarkan peluang, namun juga memunculkan persaingan, misalnya dalam dunia kuliner yang memberikan tantangan tersendiri bagi Kota Palangka Raya yaitu bagaimana mengangkat dan mengembangkan kuliner khas daerah di tengah maraknya kuliner modern. Tujuan penelitian ini adalah untuk menganalisis dan mengetahui pengembangan ekonomi kreatif di Kota Palangka khususnya pada sektor kuliner oleh-oleh khas Suku Dayak Kalimantan Tengah. Jenis penelitian ini adalah penelitian kualitatif yang dianalisis menggunakan metode deskriptif.
Kegiatan ini mendapatkan respon positif dari semua pihak demi kelancaran kegiatan seminar kami kedepannya. Besar harapan kami agar semua kegiatan ini dapat terlaksana dengan baik dan kami mengucapkan terima kasih kepada semua pihak yang mendukung kegiatan ini. Semoga pelaksaan kegiatan ini meningkatkan motivasi bagi para mahasiswa untuk lebih mengetahui makanan khas di daerahnya masingmasing. Kami berharap proposal ini dapat menjadi jambatan ilmu bagi penulis maupun pembaca terutama dalam hal tradisi adat perkawinan Dayak Ngaju. Dalam proposal penelitian ini pun kami mengharapkan kritik dan saran yang dapat membangun proposal kami lebih baik lagi kedepannya.

\section{DAFTAR PUSTAKA}

Alexandro, R. (2020, June 29). Analisis Pengembangan Ekonomi Kreatif Kuliner Khas Suku Dayak Kalimantan Tengah | Alexandro | Jurnal Ilmiah Ilmu Sosial.

Alexandro, R., Uda, T., \& Pane, L. L. (2020). Analisis Pengembangan Ekonomi Kreatif Kuliner Khas Suku Dayak Kalimantan Tengah. Jurnal Ilmiah Ilmu Sosial, 11-25.

C. (2020, September 25). Makanan Khas Kalimantan Tengah. Makananoleholeh.Com. https://makananoleholeh.com/makanan-khas-kalimantan-tengah/

Febriyana, W. (2018, May 21). Ragam Kuliner Khas Kalimantan Tengah Yang Wajib Dicoba. Mmckalteng.

Inah, E. N. (2013). PERANAN KOMUNIKASI DALAM PENDIDIKAN. Jurnal Al-Ta'dib, 6(1).

Moleong, L. J. (2010). Metodologi Penelitian Kualitatif. Remaja Rosda karya.

Nurgiansah, T. H. (2020). Filsafat Pendidikan. In Banyumas: CV Pena Persada.

Nurgiansah, T. H. (2021a). Partisipasi Politik Masyarakat Sleman di Masa Pandemi Covid-19 dalam Konteks Pendidikan Kewarganegaraan. Jurnal Civic Hukum, 6(1), 1-9.

Nurgiansah, T. H. (2021b). Pendidikan Pancasila. In Solok: CV Mitra Cendekia Media.

Nurgiansah, T. H. (2021c). Pendidikan Pancasila Sebagai Upaya Membentuk Karakter Jujur. Jurnal Pendidikan Kewarganegaraan Undiksha, 9(1), 33-41.

Nurgiansah, T. H. (2021d). Petuah Pendidikan Kewarganegaraan Dalam Kontestasi Politik. AoEJ: Academy of Education Journal, 12(1), 39-47.

Yanetri Asi Nion, R. J. (2018). Potensi Sayur Organik Lokal Daerah Rawa di Kalimantan Tengah : "Manfaat dan Tingkat Kesukaan". 259-271. 